\title{
Components and acute toxicity of nanoherbal haramonting (Rhodomyrtus tomentosa)
}

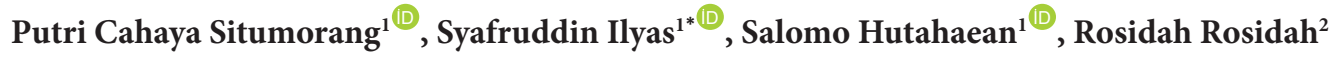 \\ ${ }^{1}$ Department of Biology, Faculty of Mathematics and Natural Sciences, Universitas Sumatera Utara, Medan, Indonesia, 20155 \\ ${ }^{2}$ Faculty of Pharmacy, Universitas Sumatera Utara, Medan, Indonesia, 20155
}

\section{A R T I C L E I N F O}

Article Type:

Original Article

Article History:

Received: 4 March 2019

Accepted: 8 June 2019

\section{Keywords:}

Nanoherbal

Haramonting

Rhodomyrtus tomentosa

LD50

\begin{abstract}
A B S T RACT
Introduction: Rhodomyrtus tomentosa (haramonting), a typical plant of North Sumatera, Indonesia, contains important medicinal ingredients. Nano sized drugs have high loading capacities and can be given at high concentrations. This study aimed to determine the components and toxicity of nanoherbal haramonting. It also aimed to determine the effect of nanoherbal haramonting on the histology of the liver, kidneys, lungs, heart and brain.

Methods: High-energy milling was performed to produce nanoherbal haramonting. Thinlayer chromatography was utilised to determine the chemical components of the nanoherb. Antioxidant tests were performed by using the 1,1-diphenyl-2-picryhydrazil method. The three-stage of lethal dose 50 (LD50) which comprised the dose orientation test, preliminary test and actual phase test/LD50 determination, and the Thomson-Weil formula was applied to measure the lethal concentration 50 (LC50) of nanoherbal haramonting. Organs were collected for histological investigation after 14 days of the lethality test.

Results: Nanoherbal haramonting had an average diameter distribution of $600.1 \mathrm{~nm} \pm 135.8$. It contained flavonoids, steroids, glycosides, saponins and tannins. Its LC50 and LD50 values were $2961.535 \mathrm{ppm}$ and $10.4 \pm 0.135 \mathrm{mg} / \mathrm{kg} \mathrm{BW}$, respectively. The histology of the heart, kidney, lungs, heart and brain were changed and affected by nanoherbal haramonting treatment at each dose level.

Conclusion: Nanoherbal haramonting has strong antioxidative activity and small size, can be effectively used as medicine in the future because it contains secondary metabolite compounds that can be developed as drugs. However, it has mild toxicity.
\end{abstract}

Implication for health policy/practice/research/medical education:

Nanoherbal haramonting possesses high antioxidant activity and small size helping in penetrating cells. It might be used as herbal medicine in the future.

Please cite this paper as: Situmorang PC, Ilyas S, Hutahaean S, Rosidah R. Components and acute toxicity of nanoherbal haramonting (Rhodomyrtus tomentosa). J Herbmed Pharmacol. 2021;10(1):139-148. doi: 10.34172/jhp.2021.15.

\section{Introduction}

Herbal plants are often used as a source of medicines because they contain small size of various bioactive ingredients, such as alkaloids, saponins, tannins, flavonoids, cardiac glycosides, steroids, terpenoids and phenolic compounds (1). The chemical compositions and uses of medicinal plants have been investigated by various scientific communities given the ability of these plants to produce innovative products with fewer side effects than chemical drugs (2). Although the extraordinary structural diversity and physicochemical and biological properties of natural products have impressed researchers, information illustrating the true potential of natural products remains lacking (3-5). Nanotechnology can produce herbal medicines with atomic, molecular, chemical, biological or catalytic scales. Transforming herbal plants into nanoscale products may increase treatment effectiveness (6).

Rhodomyrtus tomentosa (haramonting) is one of the thousands of plants in Indonesia that can be used as traditional medicine. Haramonting leaves are applied to treat colic, diarrhoea, dysentery, abscesses, bleeding, abdominal pain and wounds and to neutralise toxins $(7,8)$. 
Screening tests have shown that haramonting leaf extract has intense activity against gram-positive bacteria $(9,10)$. It also has antibacterial, antihepatitis, skin-whitening, antiageing and skin-enhancing biological activities (11). Various formulations for skin-related products, such as skin-whitening, antiageing, antiacne and skin-enhancing products, have been developed on the basis of haramonting in Indonesia (12). Malaysians also use haramonting to treat dysentery and diarrhoea (13). Haramonting has strong activities and valuable potential for development as an effective drug that can replace antibiotics or reduce antibiotic resistance in bacteria (14). The effectiveness of nanoherbal haramonting is expected to be better than that of haramonting extract. However, the application of nanoherbal haramonting has not yet been investigated in Indonesia or elsewhere. Therefore, component analysis and toxicological evaluations must be conducted to identify the safety of nanoherbal haramonting which are the main aims of this study.

\section{Materials and Methods}

Nanoherbal haramonting

The research method followed in this work was based on Patent S00201900866 (currently in the registration stage). Haramonting was collected from a residential area in Rantauprapat, Northen Sumatera and reduced to nano size through High-energy milling with $\mathrm{HCl} 2 \mathrm{M}$ activator solution (Tokyo, Japan). The characteristics and shape of nanoherbal haramonting were observed under the Axiocamp ERc 5s microscope (Germany, 2015) with $\times 40$ magnification and $\times 10000$ magnification by using a scanning electron microscope (SEM) (JSM-6390A, Tokyo, Japan). Size distribution was evaluated through particle size analysis (PSA).

Measurement of components by thin-layer chromatography Flavonoids

Nanoherbal haramonting was dissolved in ethanol and then spotted on a silica gel $60 \mathrm{~F}_{254}$ plate. The mobile phase consisted of butanol:acetic acid:water (4:1:5). The plate was observed under 354 and $366 \mathrm{~nm}$ ultraviolet light and then sprayed with hydrochloric acid (15-18).

\section{Steroids}

Nanoherbal haramonting was dissolved in ethanol and then spotted on a silica gel $60 \mathrm{~F}_{254}$ plate. The mobile phase consisted of n-hexane:ethyl acetate (80:20). The plate was observed under 354 and $366 \mathrm{~nm}$ ultraviolet light and then sprayed with anisaldehyde sulphuric acid (15-18).

\section{Glycosides}

Nanoherbal haramonting was dissolved in ethanol and then spotted on a silica gel $60 \mathrm{~F}_{254}$ plate. The mobile phase consisted of ethyl acetate:methanol:ethanol:water (81:11:4:8). The plate was observed under 354 and 366 $\mathrm{nm}$ ultraviolet light and then sprayed with $\mathrm{KOH}(15-18)$.

\section{Saponins}

Nanoherbal haramonting was dissolved in ethanol and then spotted on a silica gel $60 \mathrm{~F}_{254}$ plate. The mobile phase comprised chloroform:glacial acetic acid:formic acid:water (64:32:12:8). The plate was observed under 354 and $366 \mathrm{~nm}$ ultraviolet light and then sprayed with Lieberman-Bochard solution (15-20).

\section{Tannins}

Nanoherbal haramonting was dissolved in ethanol and then spotted on a silica gel $60 \mathrm{~F}_{254}$ plate. The mobile phase comprised ethyl acetate:methanol:ethanol:water (81:11:4:8). The plate was observed under 354 and 366 $\mathrm{nm}$ ultraviolet light and then sprayed with $\mathrm{FeCl}_{3}$ (15-18).

Characterisation of nanoherbal haramonting Ash levels

A total of $2 \mathrm{~g}$ of nanoherbal haramonting was placed in a porcelain crucible and combusted to a specific weight.

$\%$ Ashlevels $=\frac{\text { Ash weight }(g)}{\text { Sampleweight }(g)} \times 100 \%$

\section{Acid-insoluble ash content}

The ash obtained from the previous test was heated with 25 $\mathrm{mL}$ of dilute hydrochloric acid for 5 minutes until boiling. The acid-insoluble ash was filtered and then washed with hot water. The residue and filter paper were combusted to a fixed weight.

$\%$ Acid - insoluble - ash content $=\frac{\text { Ash weight }(g)}{\text { Sampleweight }(g)} \times 100 \%$

\section{Water-soluble substance content}

In this test, $5 \mathrm{~g}$ of nanoherbal haramonting was macerated in $2.5 \mathrm{~mL}$ of chloroform in $100 \mathrm{~mL}$ of water in a stoppered flask for 24 hours. The mixture was shaken frequently during the first 6 hours of maceration, allowed to stand for 18 hours and then filtered. Next, $20 \mathrm{~mL}$ of the filtrate was evaporated to dryness in a tared porcelain dish. The remaining filtrate was heated at $105^{\circ} \mathrm{C}$ to a fixed weight.

$\%$ Water-soluble-substance $=\frac{\text { Subctanceweight }(\mathrm{g})}{\text { Sample weight }(\mathrm{g})} \cdot \frac{100}{20} 100 \%$

\section{Ethanol-soluble extracts}

First, $5 \mathrm{~g}$ of nanoherbal haramonting was macerated in 100 $\mathrm{mL}$ of $96 \%$ ethanol for 24 hours in a stoppered flask. The flask was shaken during the first 6 hours of maceration and allowed to stand for 18 hours. Next, $20 \mathrm{~mL}$ of the filtrate was evaporated to dryness in a tared porcelain dish. The residual filtrate was heated at $105^{\circ} \mathrm{C}$ to a fixed weight.

$\%$ Ethanol-soluble-extracts $=\frac{\text { Substance weight }(\mathrm{g})}{\text { Sample weight }(\mathrm{g})} \cdot \frac{100}{20} 100 \%$ 


\section{Water content}

In this test, $200 \mathrm{~mL}$ of toluene and $2 \mathrm{~mL}$ of distilled water were placed in a flask and then distilled for 2 hours to the last drop. The toluene was cooled for 30 minutes, and the volume of water in the reservoir tube was read accurately as $0.05 \mathrm{~mL}$ by using a water content determination tool. A total of $5 \mathrm{~g}$ of nanoherbal haramonting was heated for 15 minutes. The temperature was increased to accelerate flow-through rate from 2 drops/s to 4 drops/s after the toluene started boiling. Distillation was continued for 5 minutes after increasing the volume of water again. Then, the receiving tube was allowed to cool at room temperature. The volume of water was read after the water and toluene had completely separated (21).

$\%$ Water Content $=\frac{\text { Volume }(m L)}{\text { Sampleweight }(g)} \times 100 \%$

Antioxidant test through the 1,1-diphenyl-2-picryhydrazil method

Nanoherbal haramonting was dissolved with methanol to a concentration of $5 \mu / \mathrm{mL}$ and homogenised thrice within 10 minutes. The solution was then centrifuged, and the clear supernatant was collected. Next, $2 \mathrm{~mL}$ of 1,1-diphenyl-2-picryhydrazil (DPPH) solution was added to $0.5 \mathrm{~mL}$ of $5 ; 10 ; 20$ and $40 \mu / \mathrm{mL}$ nanoherbal haramonting extracts with three replicates each. Absorbance was subsequently measured against methanol at a wavelength of $517 \mathrm{~nm}$ by using a UV-visible spectrophotometer.

\section{Acute toxicity test}

Lethal concentration 50 (LC50)

Toxicity was determined through the brine shrimp lethality test by using Artemia salina (Leach) larvae (22). The LC50 test was conducted by transferring Artemia larvae into $5 \mathrm{~mL}$ vial bottles containing 10, 100, 1000 or 10000 ppm nanoherbal. Mortality was observed for 24 hours, and probit values were calculated.

\section{Lethal dose 50 (LD50)}

The LD50 test involved mice (Mus musculus). The Thomson-Weil formula was used to calculate the LD50 value, which represents the dose that causes death (lethal dose) amongst $50 \%$ of experimental animals. This research was conducted in three stages: the dose orientation test (12 mice), preliminary test (20 mice) and actual test/LD50 determination (30 mice) (23). Mortality was calculated in the final stage of the test, and toxicity criteria were adjusted in accordance to Priyanto 2009 and 2010 (24,25).

\section{Histological observations}

Histological observations were performed as follows: Mice were dissected after the 14-day LD50 test. The livers, kidneys, hearts, lungs and lymph nodes of the mice were collected for observation. Tissue sections were prepared through the paraffin method and haematoxylin- eosin staining.

Statistical analysis

Histology of liver, kidneys, lung, hearts and brain were processed with Kruskal-Wallis test in SPSS 22 program.

\section{Results}

Nanoherbal haramonting

Nanoherbal haramonting appeared similar to flour and had small, fine particles (Figure 1). Microscopy observation under $\times 40$ magnification revealed nanoherbal haramonting like green crystals (Figure 2). SEM observation under $\times 10000$ magnification showed that nanoherbal haramonting resembled clots (Figure 3 ). PSA results obtained with water as a diluent indicated that nanoherbal haramonting had an average diameter of $600.1 \mathrm{~nm} \pm 135.8$. Nanoherbal haramonting had a cumulative size of $3699 \mathrm{~nm}$ and a polydispersity index of 1.204 at $25^{\circ} \mathrm{C}$. It had a refraction index of 1.3328 , viscosity of $0.8878 \mathrm{cP}$ and scattering intensity of $8622 \mathrm{cps}$ (Figure 4). Nano sized haramonting could penetrate cells effectively given its small particle size. Changing the sizes of drugs onto nanometre scales can increase drug efficacy. The results of this study are being registered under Patent S00201900866.

Observation under 354 and $366 \mathrm{~nm}$ ultraviolet light revealed that nanoherbal haramonting contained

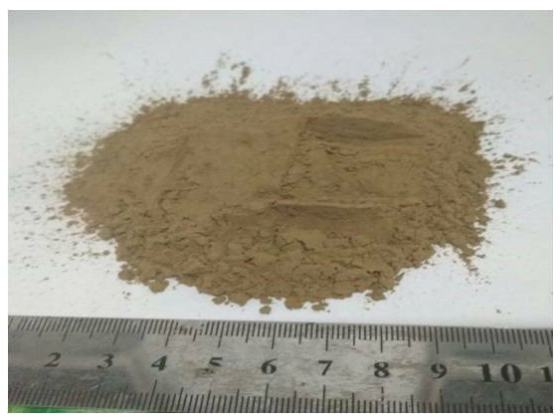

Figure 1. Nanoherbal haramonting.

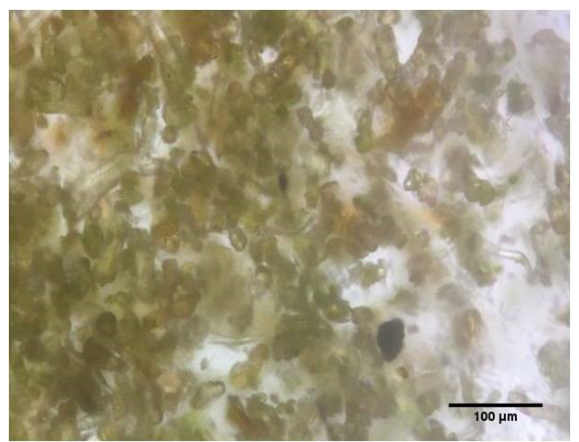

Figure 2. Nanoherbal haramonting in $x 40$ magnification. 


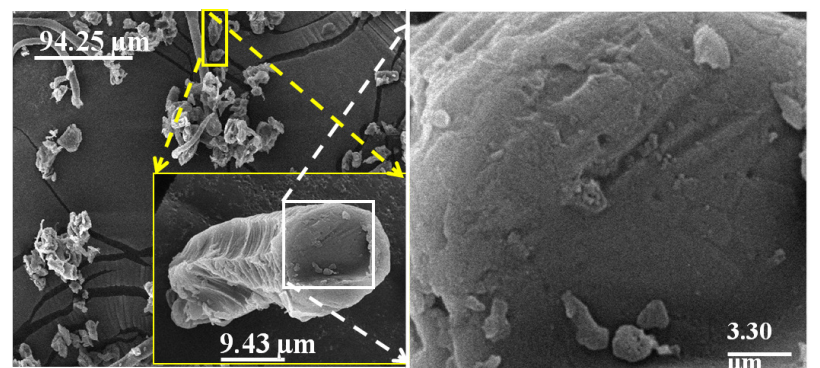

Figure 3. Nanoherbal haramonting in Scanning electron microscope (x10000).

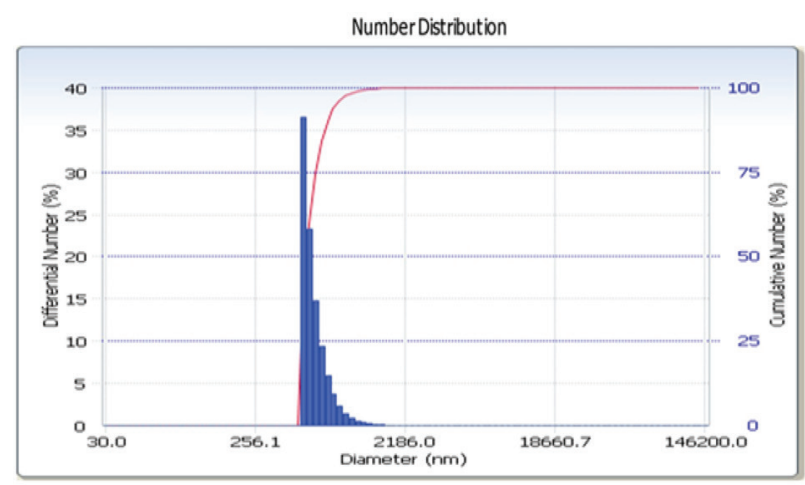

Figure 4. Nanoherbal haramonting particle size analysis results

flavonoid compounds, steroids, glycosides, saponins and tannins (Table 1). This outcome is in accordance with the results of previous research on haramonting extract. Moreover, the compounds contained by nanoherbal haramonting did not change.

The DPPH test was performed with UV-visible spectrophotometry under a wavelength of $517 \mathrm{~nm}$. The IC50 value of nanoherbal haramonting was $16.30 \mu \mathrm{g} / \mathrm{mL}$. Thus, nanoherbal haramonting had strong antioxidative activity.

Characterisation results indicated that nano sized haramonting leaf powders (Table 2) met requirements and could be developed as drugs (25-26).

The lowest larval mortality rate of $15 \%$ in LC50 was observed under treatment with 100 ppm nanoherbal haramonting, whereas the highest larval mortality rate of $65 \%$ was observed under treatment with $10000 \mathrm{ppm}$ nanoherbal haramonting (Table 3 ). The probit value is given in Table 3 and was $\mathrm{y}=1.784 \mathrm{x}-1.12$ (Figure 5). Nanoherbal haramonting has mild toxicity as reflected by its LC50 value of $2961.535 \mathrm{ppm}$.

The LD50 test was performed in three stages. The first stage was the dose orientation test. It involved treating 12 mice with 10;20;40 and $80 \mathrm{mg} / 20 \mathrm{~g}$ BW nanoherbal haramonting. Mice mortality reached $66.67 \%$ under treatment with $80 \mathrm{mg} / 20 \mathrm{~g}$ BW nanoherbal haramonting. The second stage was the preliminary test and involved 20 mice that were treated with 50,100, 200 and $400 \mathrm{mg} / 20$
Table 1. Components of nanoherbal haramonting

\begin{tabular}{lc}
\hline Components & Results \\
\hline Flavonoids & +++ \\
Alcaloids & - \\
Steroids & ++ \\
Glycosides & + \\
Saponins & ++ \\
Tannins & ++ \\
\hline
\end{tabular}

Table 2. Emulsion characterization test of nanoherbal haramonting

\begin{tabular}{lc}
\hline Parameters & Results \\
\hline Water content & $7.99 \%$ \\
Water-soluble substance content & $18.36 \%$ \\
Ethanol-soluble extracts & $8.95 \%$ \\
Ash levels & $1.88 \%$ \\
Acid-insoluble ash & $0.41 \%$ \\
\hline
\end{tabular}

Table 3. Emulsion characterization test of nanoherbal haramonting

\begin{tabular}{lccc}
\hline Concentration $(\mathbf{p p m})$ & Log10 & \% Mortality & Probit \\
\hline 10 & 1 & 0 & 0 \\
100 & 2 & 15 & 3.06 \\
1000 & 3 & 50 & 5.00 \\
10000 & 4 & 65 & 5.30 \\
\hline
\end{tabular}

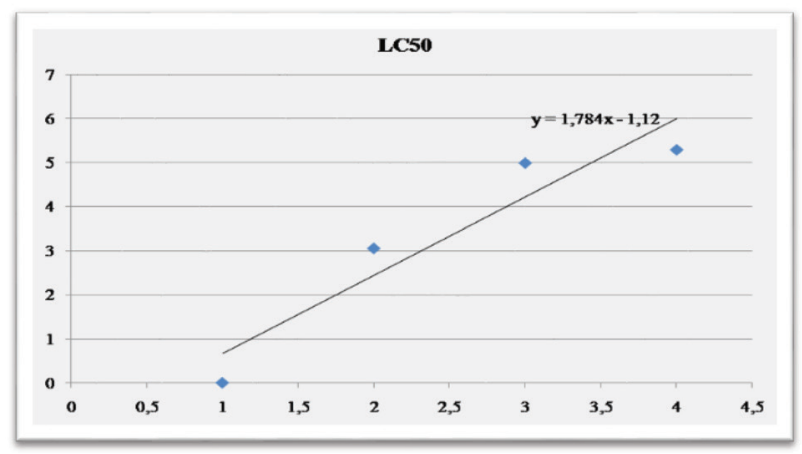

Figure 5. Graph of LC50 values.

g BW nanoherbal haramonting. Mortality rates reached $40 \%$ and $80 \%$ under treatment with 200 and $400 \mathrm{mg} / 20 \mathrm{~g}$ BW nanoherbal haramonting, respectively. The last stage involved the actual test/LD50 determination and involved 30 mice (23). The dosage and \% mortality values are presented in Table 4 . The toxicity test results indicate that nanoherbal haramonting had a LD50 value of $10.4 \pm 0.135$ $\mathrm{mg} / \mathrm{kg}$ BW and is thus mildly toxic.

Liver histology after nanoherbal haramonting administration Hepatocytes in the control group were predominantly parenchymatous. The number of normal hepatocytes began to decrease and parenchymatous degeneration 
Table 4. The last stage involved the actual test/LD50 determination

\begin{tabular}{lllll}
\hline Traetments & Mice & $\begin{array}{l}\text { Doses } \\
(\mathbf{m g} / \mathbf{2 0} \mathbf{g ~ B W})\end{array}$ & Mortality & \% Mortality \\
\hline Control & 5 & 0 & 0 & 0 \\
P1 & 5 & 100 & 0 & 0 \\
P2 & 5 & 141.42 & 1 & 20 \\
P3 & 5 & 200 & 2 & 40 \\
P4 & 5 & 282.82 & 4 & 60 \\
P5 & 5 & 400 & 5 & 80 \\
\hline
\end{tabular}

intensified in the $\mathrm{P} 1$ group. Intense hydropic degeneration, rather than parenchymatous degeneration, was observed in the P2 group. The number of cells showing hydropic degeneration and the extent of cell necrosis increased in the P3 group. The preparation colour faded, and cells appeared diffused in the $\mathrm{P} 4$ group. The number of necrotic cells increased in the P5 group, which received the highest dose of nanoherbal haramonting. The P5 group showed the most severe liver damage. The results of liver histological analyses (Figure 6) indicated that doses less than $100 \mathrm{mg} / 20 \mathrm{~g}$ BW were better than other doses.

Kidney histology after nanoherbal haramonting administration

Histological analysis showed that kidney tubules in the P1 group were narrower than those in the control group after nanoherbal haramonting administration. The colouration of histological sections from the P2 group was paler than that of the P1 group. Mice in the P2 group presented narrowed tubules. Swelling caused the tubal lumen to narrow. The number of endothelial cells surrounding the kidney tubules decreased in the P3 group (Figure 7). Most kidney tubules narrowed and even closed. The distance between kidney tubules in the P4 group shortened. Tubules narrowed and even closed in the P5 group, which received the highest dose of nanoherbal haramonting. Kidney tubule damage was more intense than glomerular damage because excess haramonting doses will be filtered through the glomerulus, enter the proximal tubule and eventually accumulate in tubular cells.

Lung histology after nanoherbal haramonting administration

Histological observations of the control, P1 and P2 groups showed thickened alveolar membranes and changes in lumen sizes and alveolar densities. The P3, P4 and P5 groups showed reduced distances between alveoli, missing cell nuclei and thin cell membranes (Figure 8). The P3, P4 and P5 groups showed similar alveolar densities and almost the same extent of damage. Membrane thickening continued in groups P1 and P2 and caused lumen deformities in group P2. The most severe damage was observed in group P5, which received the highest dose of nanoherbal haramonting. In this group, the distance between alveoli was not clearly visible.

Heart histology after nanoherbal haramonting administration

Histological analysis revealed that the heart muscle cells mainly underwent parenchymal degeneration. Each treatment dosage induced different degrees of hydropic degeneration and necrosis. Each treatment group presented different cardiac histologies, and the P3, P4 and P5 groups showed necrotic cardiac muscle cells (Figure 9). Each treatment dosage resulted in damage to cardiac muscle cells. Damage intensified in the P3, P4 and P5 groups. The arrangement of muscle cells became irregular, and nuclei began to leak from cell membranes.

Brain histology after nanoherbal haramonting administration The most extensive damage occurred in the P5 group (Figure 10). Nerve cells appeared different, cell membranes

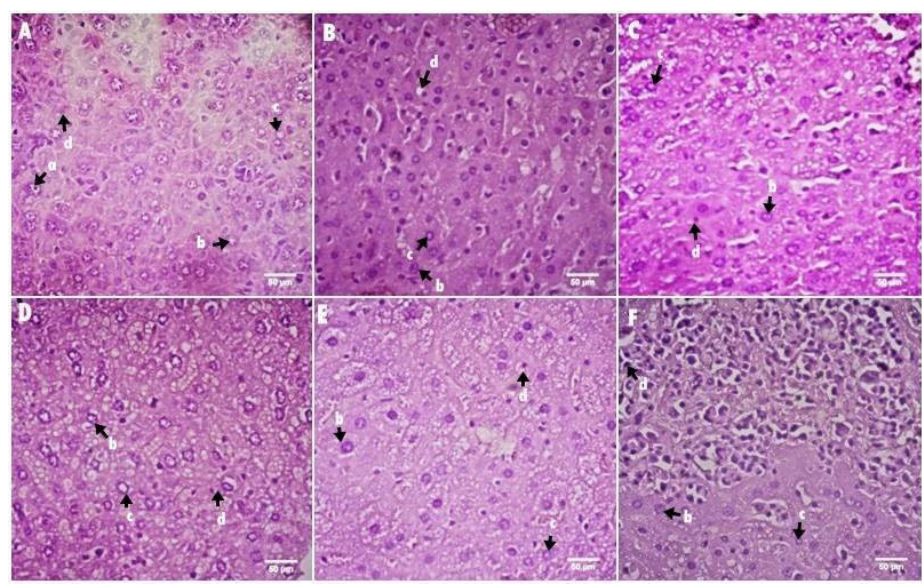

Figure 6. Liver histology after nanoherbal haramonting administration .A:Control, B: 100 mg (P1), C: 141.42 mg (P2), D:200 mg (P3), E: 282.82 mg (P4), F: $400 \mathrm{mg}$ (P5). a. Normal hepatocytes b. Parenchymatous degeneration, c. Hydropic degeneration, d. Necrosis (H\&E) x40. 


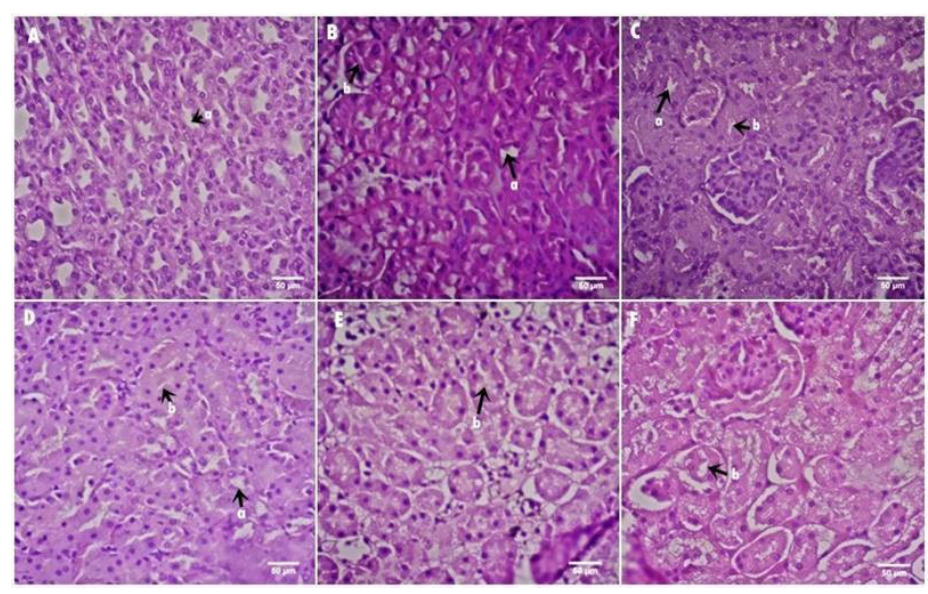

Figure 7. Kidneys histology after nanoherbal haramonting administration. A: Control, B: $100 \mathrm{mg}(\mathrm{P} 1), \mathrm{C}: 141.42 \mathrm{mg}(\mathrm{P} 2), \mathrm{D}: 200 \mathrm{mg}(\mathrm{P} 3), \mathrm{E}: 282.82 \mathrm{mg}$ (P4), F: $400 \mathrm{mg}$ (P5). a. The renal tubules normal, b. the tubules narrowed (H\&E) x40.

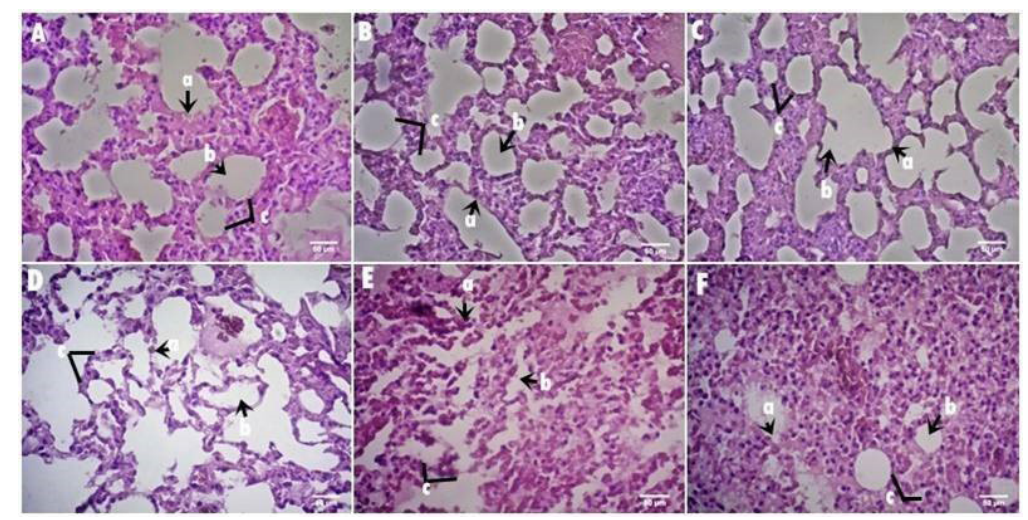

Figure 8. Lungs histology after nanoherbal haramonting administration. A: Control, B: 100 mg (P1), C: 141.42 mg (P2), D: 200 mg (P3), E: 282.82 mg (P4), F: $400 \mathrm{mg}$ (P5). a. Membrane thickness, b. Alveoli lumen, c. Distance between the alveoli (H\&E) x40.

swelled and leaked, nuclear pyknosis occurred and numerous nerve cells underwent karyolysis (cells appear blurry) in the treatment groups. Moreover, fewer normal nerve cells were observed in the treatment group than in the control. Necrosis also occurred in the control group because many factors, including pathophysiological and environmental conditions, can affect cell responses.

\section{Discussion}

PSA revealed that the average diameter of nanoherbal haramonting was $600.1 \mathrm{~nm} \pm 135$ (Figure 4). Nano size particles in this plant have exhibited increased solubility, bioavailability and stability; reduced toxicity; enhanced pharmacological activity and improved distribution in tissue macrophages, delivery and protection from physical and chemical degradation (6). The used of nanoparticle materials has a big advantage because of their size and physicochemical properties. Some of these properties can be changed through controlling the size, regulation of chemical composition, surface modification, and controlling interactions between particles. The results of measurement of PSA on nanoherbal haramonting in the form of distribution can describe the overall condition of the sample, in terms of the spread of the average size of particles in a sample. This wide surface for modification of haramonting size will increase adhesion forces which can accelerate dissolution and facilitate the entry of a nanoparticle into the cell membrane while providing a good quantum dot effect $(27,28)$. Nanoherbal superior properties in plants such as haramonting which is not owned by other types of materials, namely the ratio of surface area to volume is much greater than other materials in normal conditions. These surface properties play a very important role for the passage of a drug towards the target receptor or mass in the cell (27).

The flavonoid, steroid, glycoside, saponin and tannin contents of nanoherbal haramonting were not changed. Haramonting contains flavonoids, glycosides, phenols, amino acids, organic acids, quinones, polysaccharides and other chemical constituents and can be developed as medicinal ingredients (29). The antiseptic property of nanoherbal haramonting (IC50 $=16.30 \mu \mathrm{g} / \mathrm{mL}$ ) is stronger 


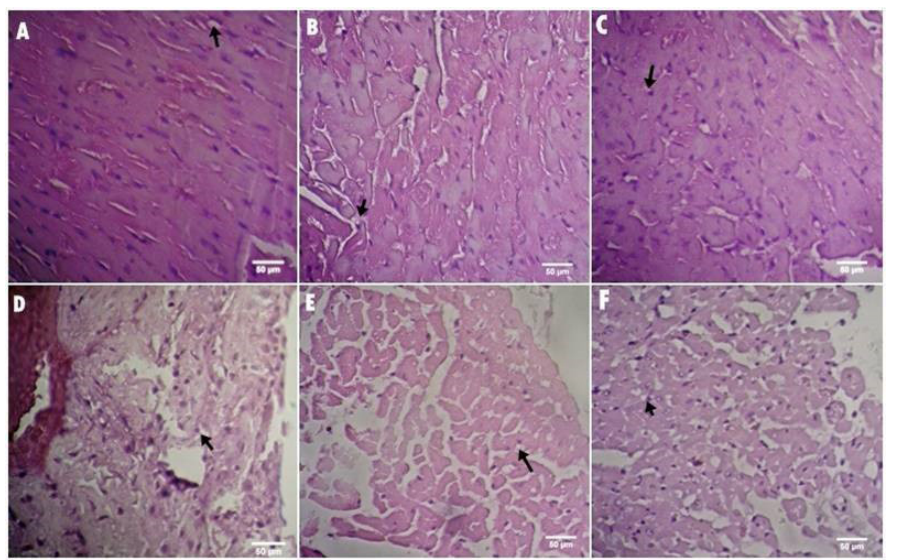

Figure 9. Hearts histology after nanoherbal haramonting administration. A: Control, B: $100 \mathrm{mg}$ (P1), C: $141.42 \mathrm{mg}$ (P2), D: $200 \mathrm{mg}$ (P3), E: 282.82 mg (P4), $\mathrm{F}: 400 \mathrm{mg}$ (P5). Arrows indicate cell necrosis (H\&E) x40.

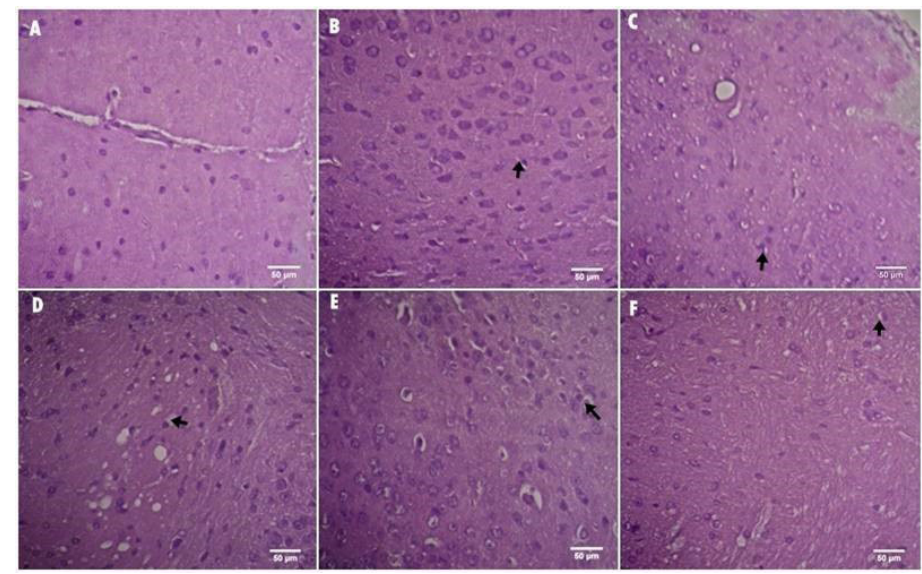

Figure 10. Brains histology after nanoherbal haramonting administration. A: Control, B: $100 \mathrm{mg}$ (P1), C: $141.42 \mathrm{mg}$ (P2), D: $200 \mathrm{mg}$ (P3), E: $282.82 \mathrm{mg}$ (P4), $\mathrm{F}: 400 \mathrm{mg}$ (P5). Arrows indicate cell necrosis (H\&E) x40.

than that of haramonting extract. Haramonting methanol extract showed intense antioxidant DPPH (EC50 110.25 $\pm 0.005 \mu \mathrm{g} / \mathrm{mL})$, CUPRAC (EC50 $53.84 \pm 0.004)$ and $\beta$-carotene bleaching (EC50 $58.62 \pm 0.001$ ) (30). Chenet et al (31) reported that the IC50 of haramonting was between 17.1 and $25.4 \mathrm{~g} / \mathrm{mL}$. $R$. tomentosa extract has strong antioxidant properties and can be used as a new source of antioxidant ingredients given its high flavonoid content (32).

Nanoherbal haramonting is mildly toxic as evidenced by its LC50 and LD50 values. Low LD50 values are associated with high toxicity. Conversely, high LD50 values are associated with low toxicity. Dosage is the most important factor that affects the toxicity of any chemical, including water. Whether small doses are ineffective or large doses are toxic or lethal should be ascertained $(33,34)$.

Liver damage is associated with cell necrosis and increased tissue lipid peroxidation and tissue GSH levels. Antioxidants may have hepatoprotective effects (35). Lipid peroxides produced in the presence of oxygen may alter the functional integrity of liver mitochondria to induce liver damage (36). Plants with high antioxidant contents are needed to prevent oxidative stress. Oxidative stress causes damage to hepatocytes (37). The natural antioxidants contained by haramonting have a beneficial effect on hepatitis induced by antitubercular agents (38). The liver-effective dose of nanoherbal haramonting is less than $100 \mathrm{mg} / 20 \mathrm{~g} \mathrm{BW}$ (39). A previous study showed that the water fraction of haramonting ethanol extract is safe for liver and heart treatment at doses of 10, 20 and $40 \mathrm{mg} /$ $\mathrm{kg} \mathrm{BW}$ and that a dose of $10 \mathrm{mg} / \mathrm{kg} \mathrm{BW}$ is safe for longterm liver treatment (39).

Doses of $100 \mathrm{mg} / \mathrm{kg} \mathrm{BW}$ and $200 \mathrm{mg} / \mathrm{kg}$ BW resulted in the development of areas with parenchymatous degeneration, inflammatory necrosis and infiltration by mixed inflammatory cells consisting of lymphocytes and neutrophils (40). Alkaline phosphatase levels increase in cases of liver toxicity because of damage to the liver parenchyma or ductal cells (41). The liver histology analysis in the present study (Figure 6) revealed extensive 
parenchymatous degeneration. The kidney damage observed after the oral administration of haramonting leaf extract may be attributed to saponins, which are membranolytics that induce bleeding in rat kidneys by triggering the disintegration of the capillary endothelial layer (42). Tubular damage can be caused by direct cell toxicity or ischemia. Shafaei et al found that haemoglobin, haeme and iron can directly damage or kill tubular cells (43). High nanoherbal haramonting doses are associated with severe damage. This outcome is in accordance with previous research showing that high doses of $70 \%$ ethanolic extracts of haramonting leaves result in intensive rat kidney damage (44).

All nanoherbal haramonting doses induced pulmonary damage. Nevertheless, the extent of damage caused by different doses did not noticeably vary (Figure 8). Inflammatory cell accumulation causes alveolar wall thickening. Damage also occurs because of uncontrollable outside variables, such as the psychological condition of the mice as a result of the surrounding environment. For example, the surrounding environment could be too noisy. Repeated handling and fighting amongst mice can also result in psychological stress. Alveolar epithelial cells were damaged as reflected by the weak relationship between alveoli and blood capillaries during alveolar gas exchange and lumen deformations.

Flavonoid and tannin compounds can cause the necrosis of heart cells. Tannin has a hydroxyl $(-\mathrm{OH})$ group that can result in the release of the respiratory chain in the mitochondria. This effect decreases ATP and induces oxidation failure. Thus, cytoplasmic granulation and parenchymatic degeneration occurs. Toxic substances can injure cells by damaging cell membranes and mitochondria and disrupting cell endogenous substrates (45). Tannins can disrupt cell wall permeability by thinning the cell wall or cell membrane. Cells cannot perform biological functions and die following cell permeability disruptions (46). The immune system can be the main target of the toxic effects of environmental pollutants (47-48).

Nanoherbal haramonting administration can reduce the number of brain nerve cells. Excessive doses decrease the number of nerve cells and may cause necrosis and histological changes that induce chronic inflammation and chronic oxidative stress and inhibit neurogenesis (49-50). Haramonting treatment resulted in white matter necrosis and was associated with calcification, fibrinoid deposition, vascular hyalinisation and endothelial thickening (51,52). The control group also exhibited necrosis (all control groups) due to pathophysiological and environmental conditions. Although the experiments were conducted under constant conditions, experimental animals may exhibit biological variations.

\section{Conclusion}

Nanoherbal haramonting can be developed as an herbal medicine in the future. It possesses emulsion characteristics that meet drug requirements and intense antioxidant activity. It possesses various components including flavonoids, steroids, glycosides, saponins and tannins. Moreover, it is mildly toxic. Its LC50 and LD50 values are $2961.535 \mathrm{ppm}$ and $10.4 \pm 0.135 \mathrm{mg} / \mathrm{kg}$ BW.

\section{Authors' contributions}

We declare that this work was done by the authors named in this article and all liabilities pertaining to claims relating to the content of this article will be borne by the authors. PCS wrote the manuscript and also worked on reparation and research. SI wrote the manuscript. SH read rat liver histology. $\mathrm{R}$ read the results of phytochemical screening and antioxidant tests. All read and confirmed the final version of the manuscript for publication.

\section{Conflict of Interests}

The authors claim that there is no conflict of interest.

\section{Ethical considerations}

Ethical issues (including plagiarism, misconduct, data fabrication, falsification, double publication or submission redundancy) have been completely observed by the authors.

\section{Funding/Support}

This study was supported by Directorate of research and community service, Directorate general of research and development, Ministry of research, Technology, and higher education in Grant of PMDSU years 2019 (Master's Education towards Doctorate 2019).

\section{References}

1. Cowan MM. Plant products as antimicrobial agents. Clin Microbiol Rev. 1999;12(4):564-82.

2. Costa EMMB, Barbosa AS, de Arruda TA, de Oliveira PT, Dametto FR, de Carvalho RA, et al. Estudo in vitro da ação antimicrobiana de extratos de plantas contra Enterococcus faecalis [In vitro antimicrobial activity of plant extracts against Enterococcus faecalis]. J Bras Patol Med Lab. 2010;46(3):175-80. doi: 10.1590/s167624442010000300004.

3. NamdariM,EatemadiA.Cardioprotectiveeffects of curcuminloaded magnetic hydrogel nanocomposite (nanocurcumin) against doxorubicin-induced cardiac toxicity in rat cardiomyocyte cell lines. Artif Cells Nanomed Biotechnol. 2017;45(4):731-9. doi: 10.1080/21691401.2016.1261033.

4. VahabiS,Eatemadi A.Nanoliposomeencapsulated anesthetics for local anesthesia application. Biomed Pharmacother. 2017;86:1-7. doi: 10.1016/j.biopha.2016.11.137.

5. Kesarwani K, Gupta R, Mukerjee A. Bioavailability enhancers of herbal origin: an overview. Asian Pac J Trop Biomed. 2013;3(4):253-66. doi: 10.1016/s22211691(13)60060-x.

6. Ansari SH, Islam F, Sameem M. Influence of nanotechnology on herbal drugs: a review. J Adv Pharm Technol Res. 2012;3(3):142-6. doi: 10.4103/2231-4040.101006. 
7. World Heatlh Organization (WHO). Medicinal Plants in Vietnam. Hanoi: Institute of Materia Medical; 1989.

8. Kissinger, Zuhud EAM, Darusman LK, Siregar IZ. Keanekaragaman jenis tumbuhan obat dari hutan kerangas. Jurnal Hutan Tropis. 2013;1(1):17-23.

9. Voravuthikunchai SP, Limsuwan S, Chusri S. New perspectives on herbal medicines for bacterial infections: natural products II. In: Govil JN, Singh VK, Siddqui NT, eds. Recent Progress in Medicinal Plants. USA: Studium Press; 2007. p. 41-101.

10. Lai TN, Herent MF, Quetin-Leclercq J, Nguyen TB, Rogez $\mathrm{H}$, Larondelle $\mathrm{Y}$, et al. Piceatannol, a potent bioactive stilbene, as major phenolic component in Rhodomyrtus tomentosa. Food Chem. 2013;138(2-3):1421-30. doi: 10.1016/j.foodchem.2012.10.125.

11. Miyake Y, Nojima J, inventor. Skin cosmetic and food/drink for cosmetrogical use. Patent JP2006199678A, 2006.

12. Saising J, Voravuthikunchai SP. Anti Propionibacterium acnes activity of rhodomyrtone, an effective compound from Rhodomyrtus tomentosa (Aiton) Hassk. leaves. Anaerobe. 2012;18(4):400-4. doi: 10.1016/j.anaerobe.2012.05.003.

13. Ong HC, Nordiana M. Malay ethno-medico botany in Machang, Kelantan, Malaysia. Fitoterapia. 1999;70(5):50213. doi: 10.1016/s0367-326x(99)00077-5.

14. Winotai A, Wright T, Goolsby JA. Herbivores in Thailand on Rhodomyrtus tomentosa (Myrtaceae), an invasive weed in Florida. Fla Entomol. 2005;88(1):104-5.

15. Waksmundzka-Hajnos M, Sherma J, Kowalska T. Thin Layer Chromatography in Phytochemistry. Boca Raton: CRC Press; 2008.

16. Harborne AJ. Phytochemical Methods A Guide to Modern Techniques of Plant Analysis. Springer Science \& Business Media; 1998.

17. Wagner H, Bladt SE, Zgainski EM. Plant Drug Analysis. Berlin, Heidelberg: Springer-Verlag; 1984.

18. Jones WP, Kinghorn DA. Extraction of Plant Secondary Metabolites. Methods in Biotechnology, Natural Products Isolation. 2nd ed. Totowa: Humana Press Inc; 2006. p. 32351.

19. Hostettmann K, Hostettmann M, Marston A. Saponins, in Terpenoids (Charlwood BV, Banthorpe DV, eds), Methods in Plant Biochemistry (Dey P M and Harborne JB eds). San Diego, CA: Academic Press;1991.

20. Wall ME, Krider MM, Krewson CF, Eddy CR, Willaman JJ, Corell DS, et al. Steroidal sapogenins. VII. Survey of plants for steroidal sapogenins and other constituents. J Am Pharm Assoc Am Pharm Assoc. 1954;43(1):1-7.

21. Ministry of Health of the Republic of Indonesia. Farmakope Indonesia (Edisi V). Jakarta: Depkes RI; 2014.

22. Donatus IA. Basic Toxicology, Laboratory of Pharmacology and Toxicology. Yogyakarta: Faculty of Pharmacy, UGM; 2005.

23. Drug and Food Supervisory Board of the Republic of Indonesia. Guidelines for Non-Clinical Toxicity Test by in Vivo, Jakarta; 2014.

24. Priyanto. Toxicology: Mechanism, antidotum therapy, and risk assessment. Indonesian Pharmacology Study and Consultation Institute (LESKONFI); 2009.

25. Priyanto. Toksikologi Ed: 2. Depok: Indonesian Pharmacology Study and Consultation Institute; 2010.

26. Ministry of Health of the Republic of Indonesia. Decree of the Minister of Health Number 661/MENKES/SK/VI /1994 about the Requirements of Traditional Medicine. Depkes RI; 1994.

27. Müller RH, Gohla S, Keck CM. State of the art of nanocrystals--special features, production, nanotoxicology aspects and intracellular delivery. Eur J Pharm Biopharm. 2011;78(1):1-9. doi: 10.1016/j.ejpb.2011.01.007.

28. Rhyner MN, Smith AM, Gao X, Mao H, Yang L, Nie S. Quantum dots and multifunctional nanoparticles: new contrast agents for tumor imaging. Nanomedicine (Lond). 2006;1(2):209-17. doi: 10.2217/17435889.1.2.209.

29. Ministry of Health of the Republic of Indonesia. Materia Medika Indonesia Ed VI. Jakarta: Directorate General of Drug and Food Control; 1985.

30. Langeland KA, Burks KC. Identification \& Biology of Non-Native Plants in Florida's Natural Areas. Gainesville: University Press of Florida; 1998.

31. Abd Hamid H, Mutazah R, Yusoff MM, Abd Karim NA Abdull Razis AF. Comparative analysis of antioxidant and antiproliferative activities of Rhodomyrtus tomentosa extracts prepared with various solvents. Food Chem Toxicol. 2017;108(Pt B):451-7. doi: 10.1016/j.fct.2016.10.004.

32. Chen T, Yu C, Yang B. Structure elucidation and NMR assignments for two new quinones from fructus rhodomyrti of Rhodomyrtus tomentosa. Chemistry of Natural Compounds. 2011;47(4):524-6. doi: 10.1007/s10600-0119987-0.

33. Wu P, Ma G, Li N, Deng Q, Yin Y, Huang R. Investigation of in vitro and in vivo antioxidant activities of flavonoids rich extract from the berries of Rhodomyrtus tomentosa (Ait.) Hassk. Food Chem. 2015;173:194-202. doi: 10.1016/j. foodchem.2014.10.023.

34. Ganiswarna SG. Farmakologi dan Terapi. Ed 5. Bagian Farmakologi FK-UI. Jakarta; 2007:823-6. [Indonesian].

35. Ariens EJ, Mutschler E, Simons AM, Pengantar TU, Terjemahan YRW, Mathilda BW. Flavonoids. Gajah Mada University Press; 1985.

36. Pramod K, Deval RG, Lakshmayya, Ramachandra SS. Antioxidant and hepatoprotective activity of tubers of Momordica tuberosa Cogn. against $\mathrm{CCl} 4$ induced liver injury in rats. Indian J Exp Biol. 2008;46(7):510-3.

37. Rubin El. The liver and biliary system. In: Essential Pathology. Lippincott Williams \& Wilkins, Wolters Kluwer Company, U.S.A; 1995.

38. Sodhi CP, Rana SF, Attri S, Mehta S, Yaiphei K, Mehta SK. Oxidative-hepatic injury of isoniazid-rifampicin in young rats subjected to protein and energy malnutrition. Drug Chem Toxicol. 1998;21(3):305-17. doi: $10.3109 / 01480549809002207$.

39. Skakun NP, Shman'ko VV. [Antioxidant effectiveness in isoniazid-induced lesions of the liver]. Farmakol Toksikol. 1986;49(4):86-9.

40. Hidayati. Efek Fraksi Air Ekstrak Etanol Daun Karamunting (Rhodomyrtus tomentosa (Ait.) Hassk.) terhadap Histologi Hati, Ginjal, dan Jantung Mencit Putih [thesis]. Farmacy Faculty Universitas Sumatera Utara; 2011.[Indonesian].

41. Geetha KM, Patil V, Murugan V. Hepatoprotective activity of aqueous alcoholic (70\%) extract of Rhodomyrtus tomentosa (Aiton) Hassk against antitubercular drugs induced hepatic damage. Int J Green Pharm. 2012;6(4):2958. doi: 10.4103/0973-8258.108212.

42. Harsh M. The liver biliary tract and exocrine pancreas. In: Text book of Pathology. New Delhi: Jaypee Brothers 
Medical Publishers (P) Ltd; 2002.

43. Shafaei H, Esmaeili A, Soleimani Rad J, Delazar A, Behjati M. Citrullus colocynthis as a medicinal or poisonous plant: a revised fact. Journal of Medicinal Plants Research. 2012;6(35):4922-7. doi: 10.5897/jmpr11.264.

44. Gutiérrez E, Egido J, Rubio-Navarro A, Buendía I, Blanco Colio LM, Toldos $\mathrm{O}$, et al. Oxidative stress, macrophage infiltration and CD163 expression are determinants of long-term renal outcome in macrohematuria-induced acute kidney injury of IgA nephropathy. Nephron Clin Pract. 2012;121(1-2):c42-53. doi: 10.1159/000342385.

45. Muthmainnah N, Trianto HF, Bangsawan PI. Uji Toksisitas Akut Ekstrak Etanol 70\% Daun Karamunting (Rhodomyrtus Tomentosa (Aiton) Hassk.) terhadap Gambaran Histopatologi Ginjal Tikus. Jurnal Mahasiswa Fakultas Kedokteran Untan. 2015;1(4):277-92. [Indonesian].

46. Cotran MD, Kumar V, Collins T. Robbins Pathologic of Disease. 6th ed. Philadelphia: WB Saunders Company; 1999.

47. Rachmawaty FJ, Citra DA, Nirwani B, Nurmasitoh T, Bowo ET. Manfaat sirih merah (Piper crocatum) sebagai agen anti bakterial terhadap bakteri gram positif dan bakteri gram negatif. Jurnal Kedokteran dan Kesehatan Indonesia.
2009;1(1):12-20.

48. Wang F, Liu F, Liu H, Chen W, Si X, Ma X. Effects of immunological and hematological parameter in mice exposed to mixture of volatile organic compounds. Inhal Toxicol. 2016;28(4):164-9. doi: $10.3109 / 08958378.2016 .1148087$.

49. Zhao W, Robbins ME. Inflammation and chronic oxidative stress in radiation-induced late normal tissue injury: therapeutic implications. Curr Med Chem. 2009;16(2):13043. doi: 10.2174/092986709787002790.

50. Belka C, Budach W, Kortmann RD, Bamberg M. Radiation induced CNS toxicity--molecular and cellular mechanisms. Br J Cancer. 2001;85(9):1233-9. doi: 10.1054/ bjoc. 2001.2100 .

51. Reinhold HS, Calvo W, Hopewell JW, van der Berg AP. Development of blood vessel-related radiation damage in the fimbria of the central nervous system. Int J Radiat Oncol Biol Phys. 1990;18(1):37-42. doi: 10.1016/03603016(90)90264-k.

52. Schultheiss TE, Kun LE, Ang KK, Stephens LC. Radiation response of the central nervous system. Int J Radiat Oncol Biol Phys. 1995;31(5):1093-112. doi: 10.1016/03603016(94)00655-5. 